\title{
Spillover of spiny lobsters Palinurus elephas from a marine reserve to an adjoining fishery
}

\author{
Raquel Goñi* ${ }^{*}$ Antoni Quetglas, Olga Reñones \\ Centro Oceanográfico de Baleares, Apdo. 291, 07080 Palma de Mallorca, Spain
}

\begin{abstract}
We investigate the effects of the Columbretes Islands Marine Reserve (CIMR, Western Mediterranean) on the adjacent Palinurus elephas (Fabricius, 1787) fishery. After 9 to $12 \mathrm{yr}$ of no-take protection there was a gradient of lobster density from the interior of the reserve up to a distance of about $4 \mathrm{~km}$ from its boundary. Catch and effort data were collected onboard commercial fishing boats in the fishery adjacent to the CIMR, and combined with catch per unit effort (CPUE) data from monitoring surveys conducted annually inside the reserve. Generalized additive (GAM) and linear (GLM) models were employed to examine the relationships of CPUE and catch per unit area (CPUA) as a function of distance to the reserve boundary. CPUE showed a significant non-linear decline with distance from the centre of the reserve, with a depression at the boundary followed by a plateau. This depression was caused by local depletion associated with concentration of fishing effort at the reserve boundary, while the plateau suggests that lobster export from the reserve is sufficient to maintain stable catch rates up to $1500 \mathrm{~m}$ from the boundary. Commercial catch and effort data were combined to estimate CPUA, which declined linearly with distance from the reserve. Analysis of recaptures of lobsters tagged and released inside the reserve indicates that the density gradient is caused by lobsters emigrating from the reserve.
\end{abstract}

KEY WORDS: Marine reserve · Spiny lobster · Spillover · Tag-recapture · Artisanal fisheries • Western Mediterranean

\section{INTRODUCTION}

Frequency-dependent models of animal distribution predict that animals should prefer to move toward areas where density is low relative to available resources if this is beneficial to their fitness (Fretwell \& Lucas 1970, Treganza \& Thompson 1998). Hence, increases in density of exploited species within no-take marine reserves could result in the enhancement of yields in neighbouring fisheries either through emigration, or through seasonal or random movements (e.g. Dugan \& Davis 1993, Roberts \& Polunin 1993, Rakitin \& Kramer 1996, Guénette et al. 1998). However, while many studies corroborate that density of exploited populations is higher in reserves than in adjacent fished areas (e.g. reviews in Roberts \& Polunin 1991, Dugan \& Davis 1993, Rowley 1994, Sánchez-Lizaso et al. 2000, Côté et al. 2001, Jennings
2001, Halpern \& Warner 2002), recent work highlights the meagre evidence available for protection effects outside marine protected areas (MPAs) (Botsford et al. 2003, Russ 2002, Russ et al. 2004). Effects on fisheries have been difficult to demonstrate empirically, partly because most marine reserves are small and were not designed for fisheries purposes, and partly due to the lack of fishery data before reserve creation, and the absence of spatial replication (Palumbi 2001, Willis et al. 2003a). In addition, few studies have investigated spillover for long enough periods to see the effect develop fully (Russ et al. 2004). The dearth of conclusive empirical work and the pressing need to assess the value of reserves as fisheries management tools has resulted in the proliferation of modelling studies (see Gerber et al. 2003 and references therein).

To address effects of reserves on fisheries some studies have monitored species density or catch per 
unit effort (CPUE) from the onset of protection in grounds adjacent to reserves; they have demonstrated increases after reserve creation (e.g. McClanahan \& Mangi 2000, Roberts et al. 2001, Galal et al. 2002, Russ et al. 2003, Murawski et al. 2004) or decreases after protection has ended (e.g. Alcalá \& Russ 1990). Other studies have measured gradients of density or CPUE across or near reserve boundaries years after reserve creation (e.g. Yamasaki \& Kuwahara 1990, McClanahan \& Kaunda-Arara 1996, Rakitin \& Kramer 1996, Russ \& Alcalá 1996, Chapman \& Kramer 1999, Johnson et al. 1999, Millar \& Willis 1999, Tupper \& Rudd 2002, Kaunda-Arara \& Rose 2004, Ashworth \& Ormond 2005). These studies have generally shown higher values closer to reserve centres for target species of low to moderate mobility. Similar results have been obtained in the few lobster studies available (Kelly et al. 2002, Davidson et al. 2002). The most convincing evidence of benefits to nearby fisheries from this type of study is the build-up of reef fish biomass (for over 2 decades) adjacent to a marine reserve in the Philippines (Russ et al. 2004). Finally, mark-recapture studies have investigated movement of protected species across no-take area boundaries. Some report emigration from reserves to the adjacent fished areas (e.g. Attwood \& Bennet 1994, Zeller \& Russ 1998, Johnson et al. 1999, Cole et al. 2000, Martell et al. 2000), but most studies do not consider immigration and thus net transfer. The few that address bi-directional movements report contrasting results (e.g. Davis \& Dodrill 1989, Rowe 2001, Zeller et al. 2003, Kelly \& MacDiarmid 2003, Tremain et al. 2004), depending on the species, life stages, habitats and size of the MPAs considered.

The Columbretes Islands Marine Reserve (CIMR) is situated in the Western Mediterranean (Fig. 1) and was designated under Spanish fisheries law in 1990. The reserve encompasses a few rocky outcrops surrounded by traditional fishing grounds of the spiny lobster Palinurus elephas (Fabricius, 1787), the most commercially important spiny lobster species in the Mediterranean and North-eastern Atlantic. Excess fishing has depleted its populations and in the NE Atlantic it is now a bycatch species of finfish netting. Although Mediterranean populations are also considered overfished, they are still targeted in many areas, especially in archipelagos and islands.

Studies conducted in the CIMR 7 to $9 \mathrm{yr}$ after its creation showed that abundance of Palinurus elephas within the reserve was 6 to 20 times greater than in comparable fished areas depending on the season (Goñi et al. 2001). The spawning potential per unit area in the reserve was also 5 to 20 times greater than in Western Mediterranean exploited areas depending on their level of exploitation (Goñi et al. 2003a). Although information on lobster abundance before

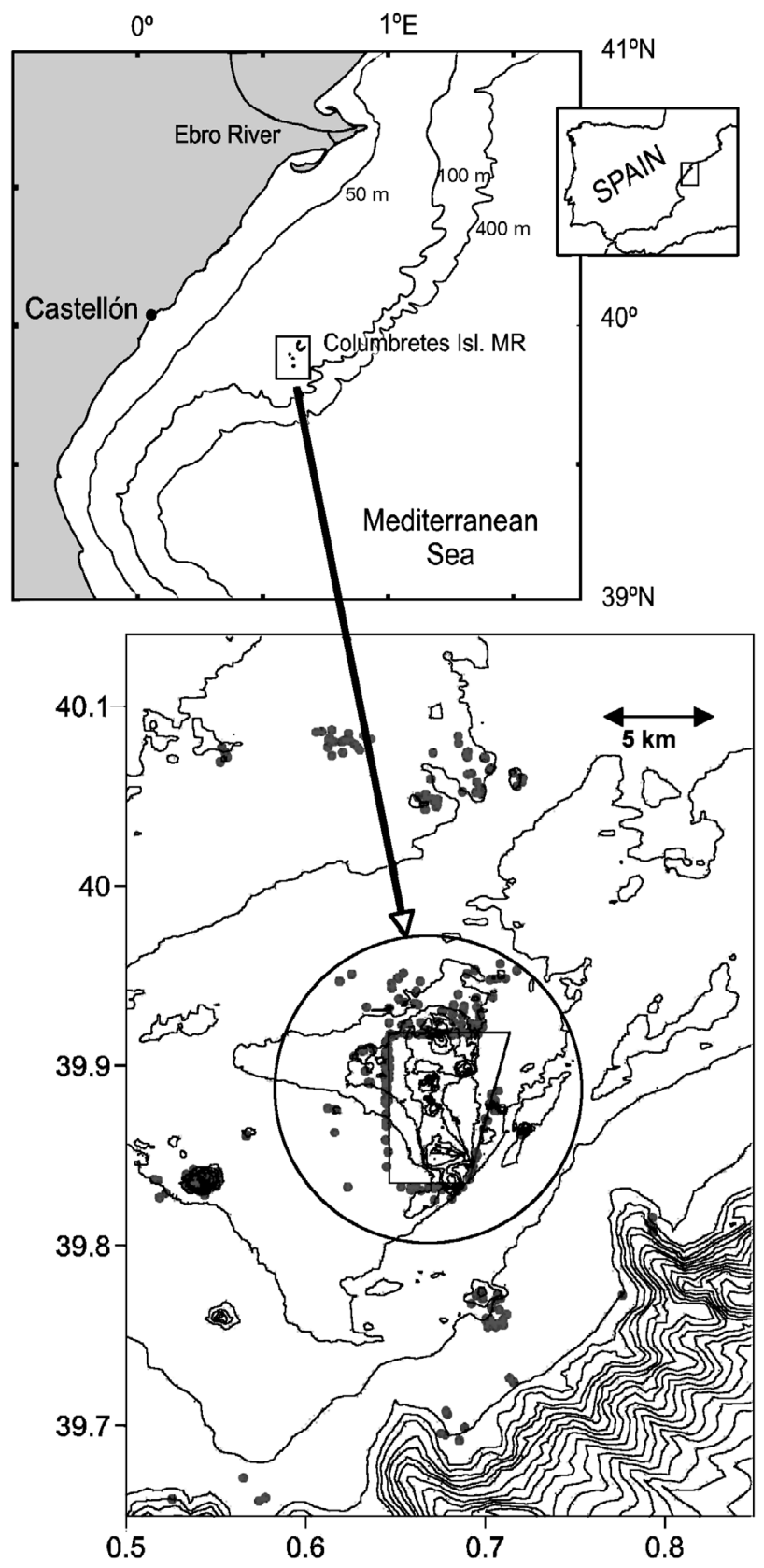

Fig. 1. Location of Columbretes Islands Marine Reserve (CIMR) on the continental shelf of the Iberian Peninsula, and bathymetric map of the study area showing (in circle) the distribution of commercial fishing sets outside the CIMR sampled for this study $(\mathrm{n}=214)$. Other dots illustrate the spatial distribution of Palinurus elephas fishing effort in the region. Experimental fishing sets inside the CIRM not shown $(\mathrm{n}=111)$

reserve implementation is not available to demonstrate that lobster density has increased inside the reserve, local fishermen corroborate that catch rates obtained in experimental fishing surveys conducted inside the CIMR since 1997 are much higher than catch rates 
they obtained in the area prior to reserve creation. Since then, commercial lobster fishing in the region occurs around the reserve and in scattered grounds 10 to $30 \mathrm{~km}$ from it. In this study we ask whether spillover of post-settlement lobsters from the CIMR is contributing to maintaining or enhancing the adjacent fishery ( $<5 \mathrm{~km}$ from the boundary). We also propose an approach for evaluating net export based on tagrecapture data. We adopt the simple definition of spillover as 'net export of postsettlers' (Russ 2002), which assumes nothing about the causative processes that could be driven by density dependent effects, random movements, or seasonal migrations from high to low density areas (Sanchez-Lizaso et al. 2000, Jennings 2001, Russ 2002).

For the study we used catch and effort data of the commercial fishery adjacent to the CIMR, CPUE data from annual experimental fishing surveys conducted inside the CIMR and data of recaptures of lobsters tagged and released inside the CIMR. To address the issue of spillover we asked 2 questions: (1) Is there a declining gradient of lobster density away from the reserve? (2) If so, is it due to movement of lobsters from the reserve to the fished areas?

We examined the spatial distribution of commercial CPUE, the effort and catch per unit area (CPUA) around the reserve, and assuming homogeneity of habitats, we predicted that if there was a negative gradient of lobster density with distance from the reserve: (1) CPUE should be highest at the boundary and decline with distance from it according to some function that will be affected by, inter alia, the spatial distribution of fishing effort, (2) fishing effort should concentrate on the boundary of the reserve, and (3) as a result of the above, CPUA should be highest near the boundary.

Data of net animal movement across MPA boundaries are rare and difficult to obtain (Russ 2002). This study was no exception, and to investigate movement from the reserve to the fished areas we used data from recaptures of lobsters tagged and released only inside the reserve. We reasoned that if both tagged and untagged lobsters were moving out of the reserve and supplying the adjacent fishery, we could make the following predictions: (1) the number of tag returns per unit effort (TPUE) in the fishery should decline with distance from the reserve and the pattern of decline should be similar to that of the CPUE, and (2) the proportion of tagged lobsters (POT) in the commercial catch should be independent of distance from the reserve. This independence should be spatially limited by the amplitude of movements of the species in the area; thus, as we move away from the reserve the probability that a fishery caught lobster did not originate from the reserve should increase.

\section{MATERIALS AND METHODS}

The species. Palinurus elephas is a slow growing spiny lobster species from temperate waters widely distributed in the Northeast Atlantic and the Mediterranean. It inhabits rocky and coralligenous habitats from near shore to depths of $200 \mathrm{~m}$; in the study area the species reaches maximum densities at depths of 60 to $90 \mathrm{~m}$. It is a long-lived (maximum estimated age $+15 \mathrm{yr}$ ), slow-growing species that reproduces once a year (Marin 1987). In the Western Mediterranean reproduction occurs from July to September, eggs hatch January to February (Goñi \& Latrouite 2005), and post-larvae puerulus settle from June to September (Díaz et al. 2001). Tagging studies conducted in the Atlantic and Mediterranean indicate that adult movement is restricted with most individuals moving less than $5 \mathrm{~km}$, although there are 2 reports of recaptures 50 and $70 \mathrm{~km}$ away (Goñi \& Latrouite 2005). Inshoreoffshore migrations linked to reproduction and feeding have been reported for both Atlantic and Mediterranean populations, and have been inferred for the CIMR population on the basis of seasonal bathymetric changes in size and sex structure (Goñi et al. 2001). Western Mediterranean fisheries are managed by a 6 mo closed season during the egg bearing period, minimum landing size, and the prohibition of landing berried females (Goñi \& Latrouite 2005).

Study site. This study took place in the CIMR and surrounding fishing grounds (Fig. 1). The reserve is located about $50 \mathrm{~km}$ from the coast and encompasses 4 small island groups. It protects $44 \mathrm{~km}^{2}$ of volcanic rock and coralligenous habitats (maërl beds) with patches of gravel, sand, and mud that extend down to depths of $80 \mathrm{~m}$. Fishing grounds adjacent to the CIMR consist of patches of rock and maërl over expanses of gravel, sand, and mud at depths of 60 to $100 \mathrm{~m}$. The CIMR was a traditional lobster fishing ground before it was closed to fishing. Since then the number of boats participating in the local lobster fishery has declined, while fishing effort per boat has increased steadily. During the study period no more than 6 boats fished consistently in the grounds near $(<5 \mathrm{~km})$ and around $(10$ to $30 \mathrm{~km})$ the CIMR (Fig. 1). The CIMR legislation prohibits most types of fishing and all lobster fishing. Although occasional poaching by recreational anglers may occur, the fishing prohibition is well enforced.

Data collection. Commercial fishery: Catch and effort of the commercial fishery was recorded from 1999 to 2002 during the 6 mo (March-August) annual lobster fishing season. Whenever possible sampling took place during one week per month on board one of the boats that fished more consistently in the region. To ensure that the data of spatial distribution of fishing effort were representative of the true distribution of 
fishing effort in the fishery, the observer sampled all the fishing sets that were carried out in that week without directing where fishing sets should be allocated.

In this fishery lobsters are caught with trammel nets (gear description in Goñi et al. 2003b) set over rocky and coralligenous habitats and soaked for several days (mean 4 to $5 \mathrm{~d}$ ), depending on weather conditions. Data on net length, soak time, location, depth, and lobster catch of every set were noted. Over the study period 214 fishing sets were recorded within $5 \mathrm{~km}$ of the reserve boundary (Fig. 1). The absence of fishing activity at distances between 5 and $10 \mathrm{~km}$ from the CIMR indicates a marked discontinuity of lobster habitats in that area (Fig. 1). In addition, $3.2 \mathrm{~km} \pm$ 1.9 $\mathrm{SD}$ is the mean distance travelled by lobsters tagged-released inside the CIMR (Goñi et al. 2003c). CPUE was calculated by the number of lobsters caught per $600 \mathrm{~m}$ of trammel net and day.

Experimental fishing: Experimental fishing surveys inside the CIMR are conducted annually between June and September as part of a monitoring programme which started in 1998. Data available from this study were for the 1998 to 2002 period, totalling 111 fishing sets. The surveys are carried out with one of the commercial boats which operate in the area, with the same crew and gear type used in commercial fishing and following a random sampling design over rock and coralligenous habitats where lobsters are known to occur. A detailed description of the survey methods is given in Goñi et al. (2003b). In surveys, net length was $600 \mathrm{~m}$ and soak time was $1 d_{i}$ thus, experimental CPUE was estimated by the number of lobsters caught per day.

Tag-recapture: Lobsters caught during the monitoring surveys inside the CIMR have been routinely tagged using Hallprint T-bar tags. Upon capture, lobsters were tagged dorso-laterally between the first and second abdominal segments and released as close as possible to the site of capture. Of 10683 lobsters tagged, 726 were recaptured up to 2002 in subsequent surveys inside the CIMR, and 85 were recaptured in the adjacent fishing grounds during the 214 commercial fishing sets studied here that had observers onboard. Over 600 more tags recaptured by fishermen outside the CIMR could not be used in this study because fishermen only recorded recapture location, effort data and the accompanying lobster catch were not provided. Also, fishermen may not report recaptures of undersized or berried lobsters.

Data analysis. Distances from both commercial and experimental fishing sets to the reserve boundary were measured from the middle point of the set to the nearest CIMR boundary. For each set we calculated CPUE, TPUE (number of tags per unit effort, estimated in the same manner as the corresponding CPUE), and POT (proportion of tagged lobsters in the catch).
The study area was divided in cells of $1 \times 1 \mathrm{~km}$. Distances from the fished cells outside the reserve to the CIMR were measured by the straight line distance from the midpoint of each cell (or from the midpoint of the portion of the cell outside the reserve for those cells that cross the boundary) to the nearest boundary. To calculate the total standardized CPUA of each cell we summed up the catch of all the sets in the cell.

Generalized additive models (GAM) and generalized linear models (GLM) were employed to explore and describe the relationships of CPUE, CPUA, TPUE and POT with distance to the reserve boundary. GLM and GAM are generalizations of multiple linear regressions; GAMs allow relating changes in these variables without restricting the functional form of the relationship (Hastie \& Tibshirani 1990, Chambers \& Hastie 1992). To fit GAM and GLM we used routines contained in the S-Plus (MathSoft Inc.) programming environment based on Hastie \& Tibshirani (1990) and functions developed by Venables \& Ripley (2000). In the models, distance to the reserve boundary was introduced as a continuous smooth variable modelled non-parametrically using a loess smoother (lo(distance)), which is a locally weighted regression smoother; depth was introduced as a covariate and, where relevant, reserve side was modelled as a 4 level factor (north, east, south, west). CPUE, TPUE and POT from experimental and commercial fishing sets were combined to study gradients across the reserve boundaries. In these analyses, experimental data from depths $<60 \mathrm{~m}$ were excluded because the commercial fishery in the area occurs at depths $>60 \mathrm{~m}$. CPUA data was modelled for commercial activity only.

The probability distributions of CPUE, CPUA and TPUA were determined by regressing the logarithm of the mean (by $500 \mathrm{~m}$ distance intervals) against the logarithm of the variance (Crawley 2003). In the 3 cases, the variance was proportional to the square of the mean and, thus, the gamma variance and logarithmic-link functions were used to relate the expected values of the variables to the predictors. To model the relationship between POT and the predictors, we used the binomial variance function and the logit-link function (Crawley 2003). To determine whether the variables explained a significant portion of the corresponding model deviance, F-tests were used, or in the case of POT the $\chi^{2}$ test (Hastie \& Tibshirani 1990). The non-linearity and the appropriate smoothing parameters of the smooth variable were assessed by the $F$ and $\chi^{2}$ tests, and by visual inspection of the fits to the observations. The deviance explained by the models was estimated by the pseudo-coefficient of determination (Swartzman et al. 1992).

Examination of the benthos bycatch of each fishing operation sampled indicated no measurable differences in bottom habitat, suggesting that all fishing 
operations took place over similar habitats. The patchy distribution of the fishing activity supported this assumption (Fig. 1). Thus, for the purpose of this study we assumed homogeneity of habitat quality in all the areas where fishing had taken place. Year and seasonal (month) effects on the modelled variables could not be explored due to the small sample size of the various year-month combinations.

\section{RESULTS}

\section{Catch per unit effort}

Experimental CPUE inside the reserve ranged from 4 to 154 lobsters per $600 \mathrm{~m}$ of net per day, while commercial CPUE adjacent to the reserve ranged from 0 to 10 lobsters per $600 \mathrm{~m}$ of net per day (Fig. 2). Analysis of deviance of combined experimental and commercial CPUE as a function of distance to the reserve using GAM (Table 1) indicated a significant non-linear relationship ( $\mathrm{p}<0.01)$. There was also a significant negative linear relationship between CPUE and depth $(p=0.011)$. The model explained a large fraction of the deviance in the data (pseudo $\mathrm{R}^{2}=0.85$ ). Fitted values for GAM, including $95 \%$ confidence intervals (Fig. 3a), show an abrupt downward gradient of CPUE from inside to outside the CIMR.

Results of GAM of commercial CPUE outside the reserve as a function of distance from the boundary (Table 2) indicated a significant non-linear negative relationship ( $\mathrm{p}<0.01)$. CPUE also decreased linearly with depth ( $p=0.033)$, but was not affected by the side of the reserve $(p=0.52)$. The model explained a small fraction of the deviance in the data (pseudo $\mathrm{R}^{2}=0.20$ ). The fitted values for the GAM showed that the nonlinearity of CPUE with distance was due to a local CPUE minimum, followed by a plateau within $1500 \mathrm{~m}$ of the reserve boundary (Fig. 3b). After the plateau, CPUE declined linearly with distance.
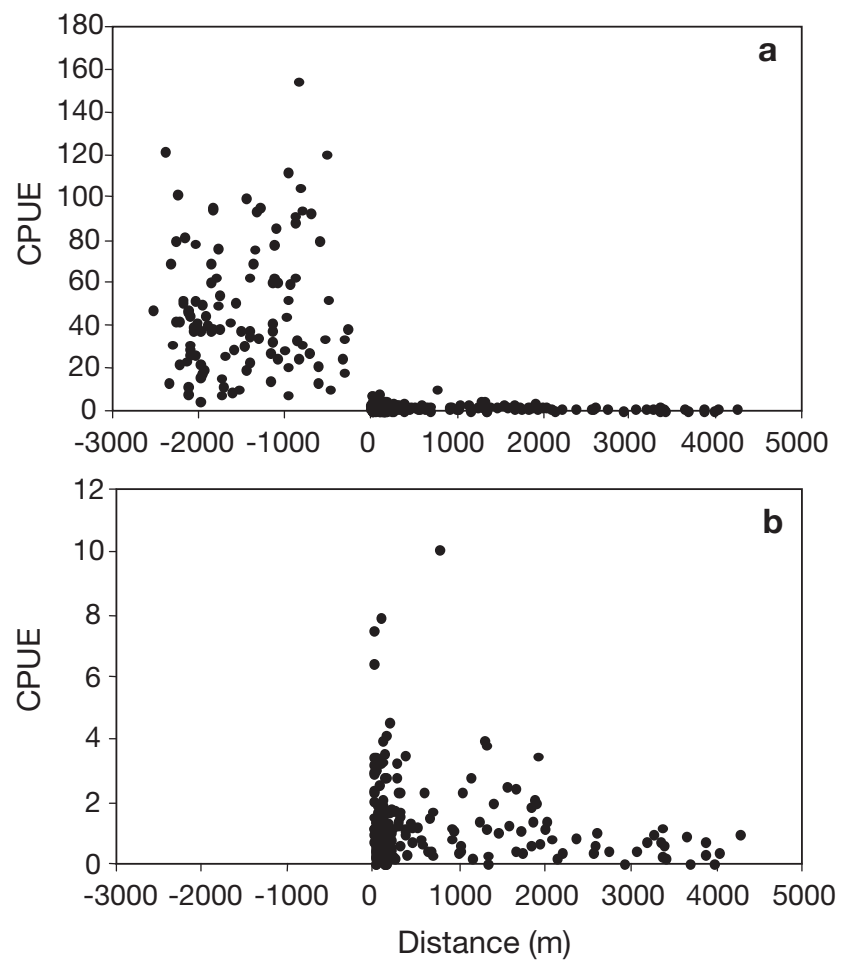

Fig. 2. Palinurus elephas. CPUE (number of lobsters caught per $600 \mathrm{~m}$ of net per day) versus distance from fishing set to the reserve boundary. (a) Commercial and experimental data combined, (b) commercial fishery data on expanded y-axis scale

boundary, with productivity declining rapidly with distance, however, there were also fished cells adjacent to the reserve that produced small catches (Fig. 5). Results of the GAM (not shown) indicated a linear effect of distance from the boundary on CPUA. Accordingly, a GLM was fitted to CPUA with distance from the boundary as a predictor, and depth and reserve side as covariates. Analysis of deviance (Table 3) showed a significant effect of distance ( $p<$ $0.01)$, and non-significant effects of depth $(p=0.988)$ or

\section{Effort}

The cumulative distribution of fishing effort (Fig. 4) showed high effort concentration near the CIMR with about $75 \%$ of the fishing sets deployed within $1 \mathrm{~km}$ of the boundary.

\section{Catch per unit area}

The most productive cells were located within $1 \mathrm{~km}$ of the reserve
Table 1. Analysis of deviance for GAM fitted to combined experimental and commercial CPUE (catch per unit effort) data. Distance to reserve boundary is -3000 to $+5000 \mathrm{~m}$. - : inside reserve; + : outside reserve. Term: the variables in the model. Res. dev and Res. df: deviance and degrees of freedom of the model. Test: the variable excluded from the full model, with df and Dev being the difference excluding the tested variable. The probability column corresponds to the significance of the deviance portion explained by each model term. lo(distance): locally weighted regression smoother 'loess'

\begin{tabular}{|c|c|c|c|c|c|c|c|}
\hline Term & Res.dev & Res. df & Test & $\mathrm{df}$ & Dev & $F$ & $\mathrm{p}(F)$ \\
\hline Null & 973.54 & 266 & & & & & \\
\hline lo(distance)+depth & 141.68 & 258 & & & & & \\
\hline lo(distance) & & & -depth & 1 & 4.16 & 5.066 & 0.011 \\
\hline depth & & & -lo(distance) & 6 & 422.88 & 80.709 & $<0.01$ \\
\hline
\end{tabular}



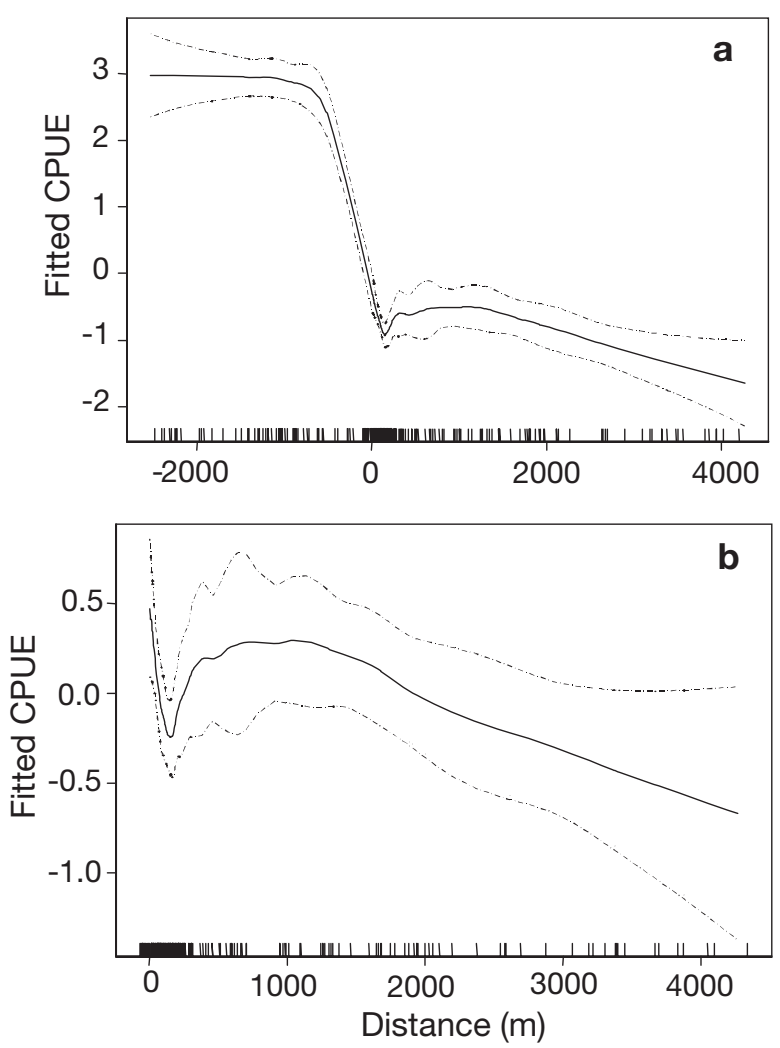

Fig. 3. Palinurus elephas. Fitted mean CPUE as a function of distance from fishing set to the reserve boundary derived from GAM. (a) Commercial and experimental data combined, (b) commercial data only. Models incorporate logarithmic link, gamma variance function, smooth variable distance, linear predictor depth and factor side (in b only). Each plot is the contribution of the tested variable to the additive predictor. Units in the $y$-axis are scaled so that zero corresponds to the mean in the link scale. Marks in the $x$-axis indicate individual observations. Dashed lines indicate 2 standard errors

side $(p=0.502)$. The model explained about half the deviance in the data (pseudo $\mathrm{R}^{2}=0.47$ ). The model fit showed that CPUA declined exponentially (linear in a log scale) as distance from the reserve increased (Fig. 6).

\section{Tags per unit effort}

TPUE in experimental fishing sets inside the reserve ranged from 1 to 31 tags per $600 \mathrm{~m}$ of net per day (TPUE $=0$ in $20 \%$ of the sets), and in the commercial fishery from 0.04 to 0.55 tags per $600 \mathrm{~m}$ of net per day (TPUE $=0$ in $77 \%$ of the sets) (Fig. 7). No tags were recovered beyond $1500 \mathrm{~m}$ from the reserve boundary and we modelled TPUE as a function of distance up to $+1500 \mathrm{~m}$ from

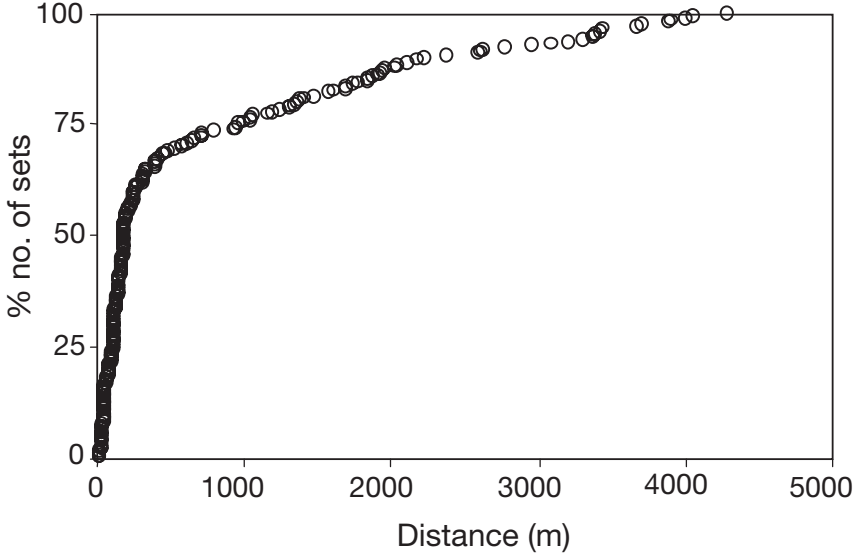

Fig. 4. Cumulative distribution of fishing effort in the Palinurus elephas fishery adjacent to the CIMR as a function of distance to the reserve boundary

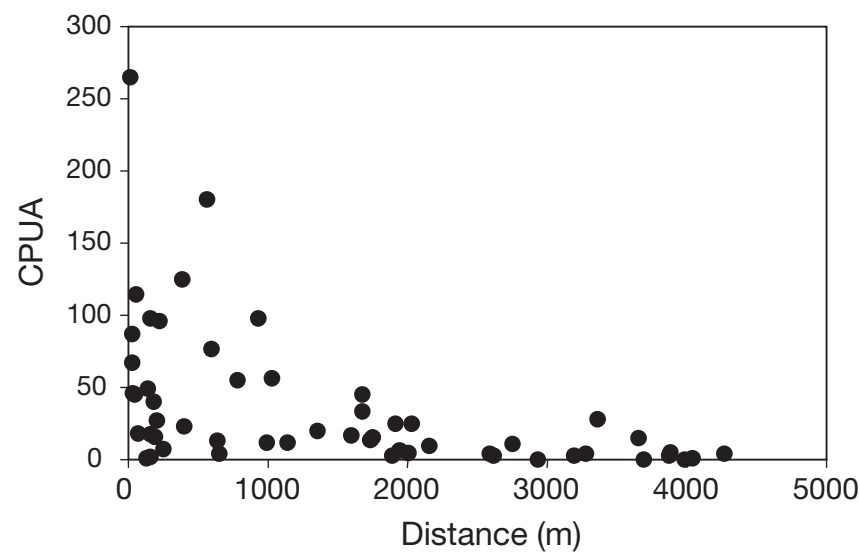

Fig. 5. Palinurus elephas. CPUA (commercial catch in number of lobster per cell) against distance from cell to the CIMR boundary

the boundary. TPUEs were transformed (TPUE+ 0.01) to eliminate zeroes.

Analysis of deviance of combined experimental and commercial TPUE as a function of distance to the reserve boundary and depth using GAM (Table 4 ) indicated a significant non-linear relationship with distance $(\mathrm{p}<0.01)$, and no-significant relationship with

Table 2. Analysis of deviance for GAM fitted to CPUE (catch per unit effort) data from the commercial fishery. Distance to reserve boundary is 0 to $+5000 \mathrm{~m}$. The interaction of distance:side (not significant) is excluded from the model. Other information as in Table 1

\begin{tabular}{|lrrlrrrr|}
\hline Term & Res.dev & Res.df & Test & df & Dev & $F$ & $\mathrm{p}(F)$ \\
\hline Null & 140.37 & 210 & & & & & \\
lo(distance)+depth+side & 112.39 & 200 & & & & & \\
lo(distance)+depth & 114.46 & 203 & -side & 3 & 2.06 & 0.756 & 0.520 \\
lo(distance)+side & 116.57 & 201 & -depth & 1 & 4.17 & 4.588 & 0.033 \\
depth+side & 127.99 & 205 & -lo(distance) & 5 & 15.59 & 3.229 & $<0.01$ \\
\hline
\end{tabular}


depth $(p=0.543)$. The model explained a large portion of the deviance (Pseudo $\left.\mathrm{R}^{2}=0.70\right)$. Fitted values for GAM (Fig. 8a) showed an abrupt decline in TPUE across the reserve boundary.

Analysis of deviance of commercial TPUE indicated non-significant relationships with distance $(p=0.121)$, depth $(\mathrm{p}=0.762)$ and reserve side $(\mathrm{p}=$ 0.077) (Table 5). The model explained a small fraction of the deviance (Pseudo $\left.\mathrm{R}^{2}=0.15\right)$. The fitted values for the GAM showed that mean TPUE declined just outside the reserve and rose to a plateau extending to $1500 \mathrm{~m}$ from the reserve boundary (Fig. 8b).

\section{Proportion tagged}

Highest values of POT were found near the boundary and the range of values inside and outside was similar (Fig. 9). As no tags were recovered beyond $1500 \mathrm{~m}$ from the boundary, we modelled POT of sets with lobster catch as a function of distance up to $+1500 \mathrm{~m}$ from the boundary.

Analysis of deviance of the combined experimental and commercial POT data as a function of distance, and accounting for depth using GAM, indicated non-significant relationships between POT and distance from the reserve boundary ( $p=0.419)$, or depth $(p=0.471)$ (Table 6, Fig. 10a); the model explained little of the variance of POT (pseudo $\mathrm{R}^{2}=0.16$ ). The fitted values for the GAM showed that mean POT was constant inside

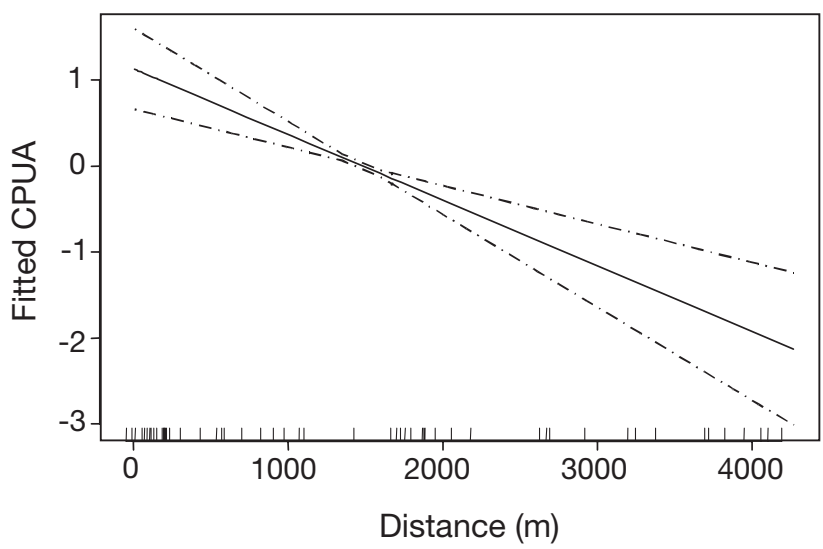

Fig. 6. Palinurus elephas. Fitted mean commercial CPUA (commercial catch in number of lobster per cell) as function of distance from cell to the CIMR boundary, accounting for depth and side, derived from a GLM incorporating logarithmic link and gamma variance functions. Other information as in Fig. 3 the reserve and declined just outside the boundary due to the concentration of sets with low lobster catch that yielded no tags (Fig. 8b). Analysis of deviance of com-
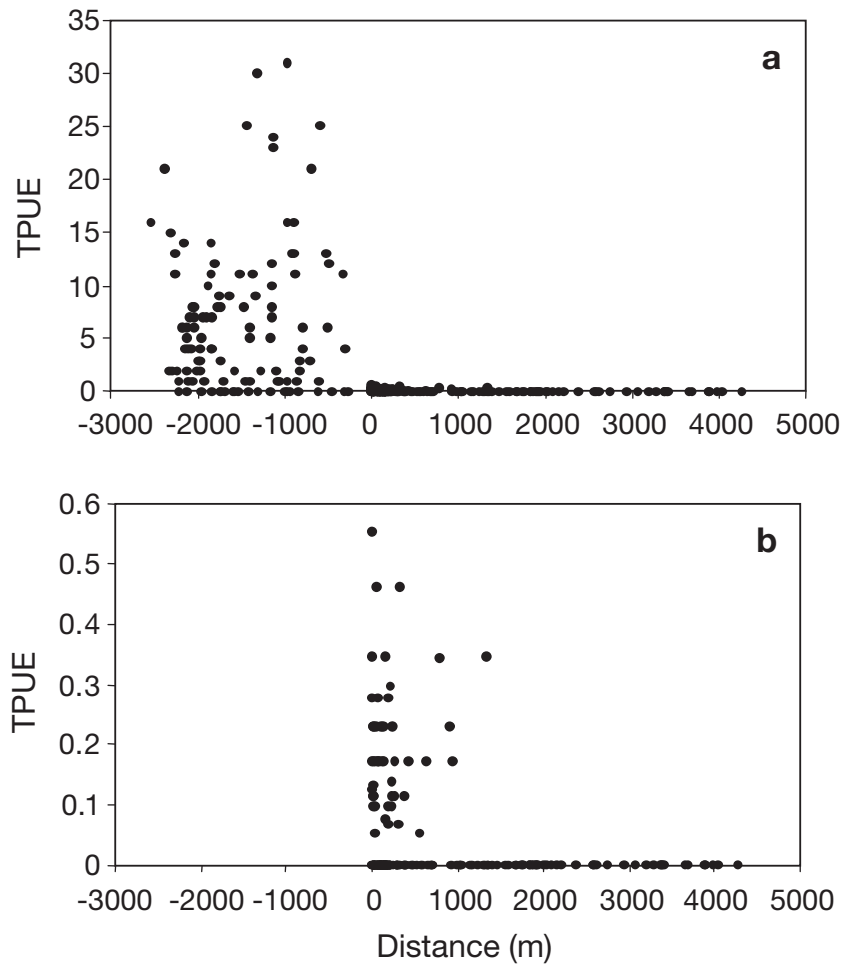

Fig. 7. Palinurus elephas. TPUE (number of tags per $600 \mathrm{~m}$ of net per day) against distance from fishing set to the reserve boundary. (a) Commercial and experimental data combined,

(b) commercial fishery data on expanded $y$-axis scale 

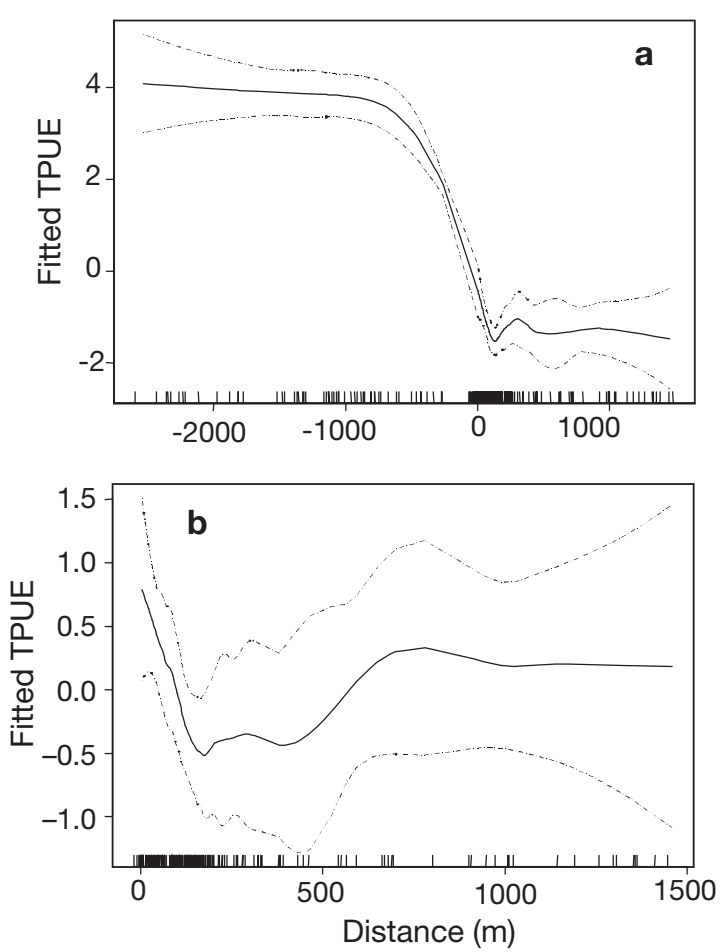

Fig. 8. Palinurus elephas. Fitted mean TPUE (number of tags per $600 \mathrm{~m}$ of net per day) as a function of distance from fishing set to the reserve boundary derived from GAM. (a) Commercial and experimental data combined, (b) commercial data only. Other information as in Fig. 3

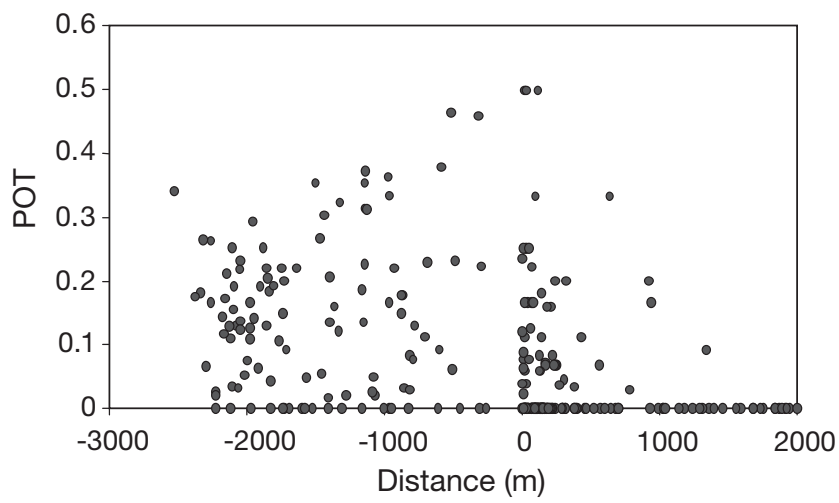

Fig. 9. Palinurus elephas. POT (proportion of tagged lobsters) in commercial and experimental fishing sets against distance from fishing set to the reserve boundary

mercial POT outside the reserve yielded non-significant relationships between POT and distance, depth or side (pseudo $\mathrm{R}^{2}=0.17$ ) (Table 7, Fig. 10b).

\section{DISCUSSION}

Net emigration of animals across reserve boundaries should create a gradient of density whose spatial pat-
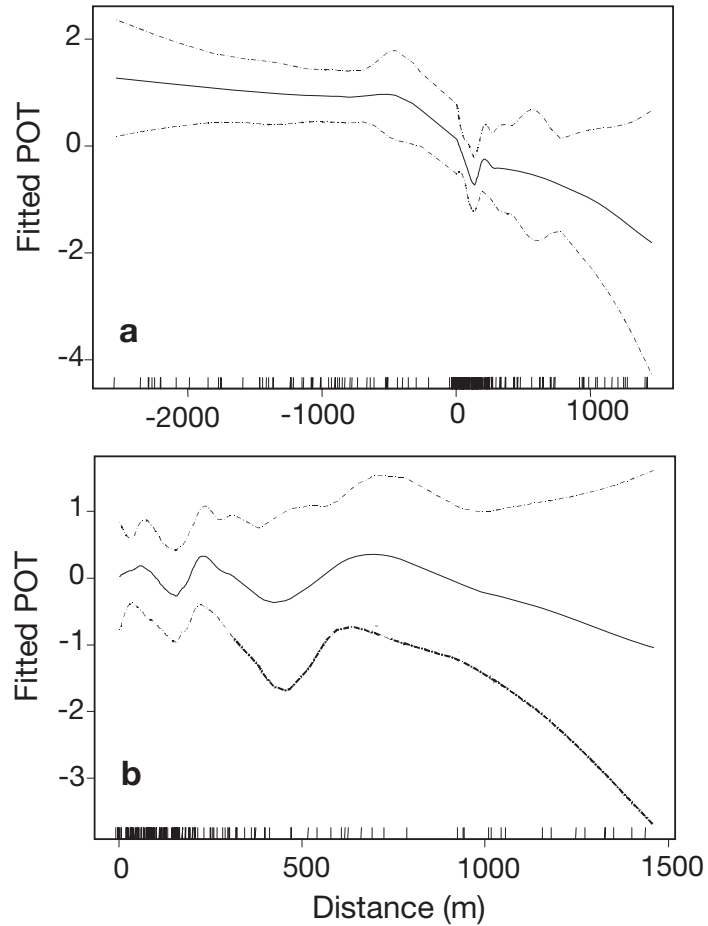

Fig. 10. Palinurus elephas. Fitted mean POT (proportion of tagged lobsters) as a function of distance from fishing set to the reserve boundary derived from GAM. (a) Commercial and experimental data combined, (b) commercial data only. Models incorporate logit link and binomial variance functions, smooth variable distance, linear predictor depth and factor side (in b only). Other information as in Fig. 3

tern will depend on the movement behaviour as well as on the catchability and exploitation rates of the species in the adjacent fishery (Rakitin \& Kramer 1996, Russ et al. 2003). In this study we used a combination of tag-recapture methods, fishing surveys and commercial fishery data to demonstrate the existence of a negative gradient of lobster density up to $4.5 \mathrm{~km}$ away from the CIMR. Tagging data, although not conclusive, provided evidence that the density gradient is caused by spillover of lobsters from the reserve. Our approach is novel in that it combines survey and commercial CPUE data to study gradients across reserve boundaries, explicitly incorporates commercial fishing effort to derive density gradients outside the reserve, and uses tag-recapture information to examine the origin of the lobsters caught in the adjacent fishery. Although applied in a variety of studies in marine ecology (e.g. Swartzman et al. 1992, Adlerstein \& Welleman 2000, Denis et al. 2002), the use of GAMs to explore and describe gradients in the context of MPAs is also novel.

Lobster CPUE declined abruptly at the reserve boundary in accordance with the high catchability (Goñi et al. 2003b), and exploitation rates in the adjacent lobster fishery (Goñi et al. 2000); as well as with 
Table 5. Analysis of deviance for GAM fitted to commercial TPUE (tags per unit effort) data. Distance to reserve boundary is 0 to $+1500 \mathrm{~m}$. The interaction of distance:side (not significant) is excluded from the model. Other information as in Table 1

\begin{tabular}{|lcclcccc|}
\hline Term & Res.dev & Res.df & Test & df & Dev & $F$ & $\mathrm{p}(F)$ \\
\hline Null & 354.03 & 171 & & & & & \\
lo(distance)+depth+side & 301.65 & 162 & & & & & \\
lo(distance)+depth & 322.14 & 165 & -side & 3 & 20.48 & 2.316 & 0.077 \\
lo(distance)+side & 301.93 & 163 & -depth & 1 & 0.27 & 0.092 & 0.762 \\
depth+side & 327.18 & 167 & -lo(distance) 5 & 25.52 & 1.787 & 0.121 \\
\hline
\end{tabular}

Table 6. Analysis of deviance for GAM fitted to combined experimental and commercial POT (proportion of tagged lobsters) data. Sets with lobster catch = 0 are excluded. Distance to reserve boundary is -3000 to $+1500 \mathrm{~m}$. Other information as in Table 1

\begin{tabular}{|lcclccc|}
\hline Term & Res. dev & Res. df & Test & df & Dev & $p\left(\chi^{2}\right)$ \\
\hline Null & 42.95 & 220 & & & & \\
distance+depth & 36.45 & 213 & & & & \\
lo(distance) & & & -depth & 1 & 0.51 & 0.471 \\
depth & & & -lo(distance) & 6 & 6.418 & 0.419 \\
\hline
\end{tabular}

Table 7. Analysis of deviance for GAM fitted to commercial POT (proportion of tagged lobsters) data. Sets with lobster catch $=0$ are excluded. Distance to reserve boundary is 0 to $+1500 \mathrm{~m}$. The interaction of distance:side (not significant) is excluded from the model. Other information as in Table 1

\begin{tabular}{|lcclccc|}
\hline Term & Res. dev & Res. df & Test & df & Dev & $p\left(\chi^{2}\right)$ \\
\hline Null & 31.31 & 164 & & & & \\
distance+depth +side & 26.40 & 155 & & & & \\
distance+depth & 28.15 & 158 & -side & 3 & 1.75 & 0.626 \\
distance+side & 26.63 & 156 & -depth & 1 & 0.24 & 0.623 \\
depth+side & 27.34 & 160 & -distance & 5 & 0.94 & 0.959 \\
\hline
\end{tabular}

the limited movement of the species (see below). Within the range of tag recoveries (up to +1500), the pattern of decline of catch rates of tagged lobsters across the reserve boundary was similar to that of the CPUE; this was expected if the tagged population in the reserve was well mixed and behaved similarly to the non-tagged population. Both sets of data showed a similar pattern of decline with distance from the centre of the reserve, with a depression at the boundary followed by a plateau, and a linear decline as distance increases in the case of CPUE. The CPUE depression, also noted by McClanahan \& Mangi (2000) and Willis et al. (2003b), was associated with high levels of fishing effort near the reserve ('edge fishing' or 'fishing the line') causing local depletion (see below). McClanahan \& Kaunda-Arara (1996) suggested that intense edge fishing was enough to collect all of the fish export from a marine reserve in Kenya. In our case the plateau following the depression suggests that export from the reserve was sufficient to maintain stable catch rates up to $1500 \mathrm{~m}$ from the boundary. As distance increased, the limited mobility of Palinurus elephas and the high fishing pressure combined to gradually reduce the number of available lobsters.

Despite lower catch rates near the boundary, fishermen preferred the edge of the reserve to set their nets. One characteristic of the fishing effort exerted on the boundaries, which contributes to the observed local depression in catch rates, is the strategy of fishers to occupy those desirable fishing spots through the season regardless of catch rates. Effort concentration along the boundaries of marine reserves has been noted by many authors studying fisheries near MPAs (e.g. Yamasaki \& Kuwahara 1990, Johnson et al. 1999, McClanahan \& Mangi 2000, Murawski et al. 2005, Kelly et al. 2002, Willis et al. 2003b, Ashworth \& Ormond 2005). In fishing grounds not associated with reserves fishermen tend to relocate their nets when catch rates drop.

Maury \& Gascuel (2001) examined the local overfishing phenomenon as a function of the detection and fishing efficiency of the vessels involved and their degree of cooperation (or spying). The case of the lobster trammel-net fishery around the CIMR fits best in their category 1 , where the vessels, although with low detection capacity, are endowed with high fishing capacity inducing high local rates of exploitation. Under such circumstances, they deplete the area quite rapidly and their yields fall markedly when effort increases. In the extreme, if vessels always fished in the same place and exerted very high local fishing mortality, they would catch (at each time step) all the lobster diffusing from the unfished zone (high local rates of exploitation compared with diffusive replacement).

When commercial CPUE and effort data were combined to estimate lobster catch per unit area as a function of distance from the reserve, we obtained a linear decline. This negative gradient of lobster catch away from the reserve supports the idea that the local depletion in CPUE observed near the reserve was caused by the spillover of lobster in that area being harvested at a greater rate than further away. This result emphasizes the importance of knowing the distribution of fishing 
effort to assess the fishery effects of reserves, and indicates that such assessments should consider cumulative spatial effects (Walters 2000).

The ratio of tagged lobsters in the commercial catch was independent of distance from the fishing set to the boundary up to a distance of $1500 \mathrm{~m}$, beyond which no tagged lobsters were recaptured. This result, although not conclusive given the large number of zeroes in the data, suggests that the reserve population was supplying the adjacent fishery and that the spatial extent of this effect was at least $1500 \mathrm{~m}$. The precise extent of the influence of the reserve is difficult to assess from the tagging data due to the large number of sets with very small catches in the fishery. Examination of the relationship between the size of the lobster catch and the number of tag recoveries in experimental sets inside the CIMR indicated a positive linear relationship with a slope of $\sim 7$, indicating that on average, to obtain a tag recovery, it was necessary to catch 7 lobsters (or that about $14 \%$ of the population in the reserve was tagged). However, only $43 \%$ of the commercial fishing sets studied had a lobster catch of 7 compared to $97 \%$ inside the reserve. Therefore, POT estimates of sets with low lobster catch may not be representative of the POT values in the area; this is illustrated by the (nonsignificant) depression in fitted POT near the boundary (Fig. 10a). However, the large number of zeroes in the data may also indicate that tagged lobsters emigrating from the reserve are mixing with non-tagged lobsters from the outside population. With the available data it is not possible to estimate the relative contribution of the 2 effects on POT as distance from the reserve increases. We conclude that the applicability of unidirectional tagging data to infer spillover may pose problems as differences in population abundance inside and outside the MPA increase.

Preliminary results of the tag-recapture study and of previous studies indicate that adult and subadult Palinurus elephas undertake limited movements (Hepper 1977, Marin 1987), on average not exceeding $3.2 \mathrm{~km} \pm$ 1.9 SD in the study area (Goñi et al. 2003c). However, in our tag-release programme a small number of tags had been recaptured at greater distances (up to $20 \mathrm{~km}$ ) from the CIMR. It is, therefore, somewhat surprising that in the fishing sets studied here no tagged lobsters were caught beyond $1500 \mathrm{~m}$. Note that, given the large size of the CIMR, a lobster tagged inside the reserve and recaptured $1500 \mathrm{~m}$ away from it may have moved several kilometres depending on the precise location of release. It is also possible that a few lobsters moving out of the CIMR during the fishery closed season (September to February) were able to reach greater distances and be harvested in distant fishing grounds the next season. This would be consistent with hypothesized winter-spring inshore and fall offshore migra- tions of segments of the protected population (Goñi et al. 2001). In this case, our sample of commercial fishing sets may be too small to fully represent the spatial distribution of tag recaptures. Hence, this result should be interpreted with caution.

Kelly et al. (2002) concluded that lobster Jasus edwardsii spilled over from the Leigh marine reserve in New Zealand because CPUE around the reserve (that encloses inshore reefs), was similar to CPUE in other inshore reefs. The high variability of catches adjacent to the reserve and the movement patterns of the species from tag recapture studies supported their conclusion (Kelly 2001, Kelly \& MacDiarmid 2003). Although seasonal variability could not be studied here, variability of catch rates of Palinurus elephas was also highest near the CIMR (as was sample size), possibly reflecting fluctuations associated with seasonal movements. Kelly \& MacDiarmid (2003) observed that despite the great site fidelity of $J$. edwardsii, $20 \%$ of the lobsters registered movements in and out of the Leigh marine reserve, and they attributed these movements to homing behaviour. The study of a more mobile decapod, the crab Chionoecetes opilio, reported declining gradients of CPUE extending up to $13 \mathrm{~km}$ from a no-take area off Japan (Yamasaki \& Kuwahara 1990).

Thus far, in our ongoing tag-recapture study, about $50 \%$ of the recaptures of lobsters tagged in the reserve have been caught outside the CIMR (Goñi et al. unpubl. data). Tag-recapture studies in reserves have been criticized because they do not provide information on net emigration rates that are required to truly assess spillover (Russ 2002). But conditions needed to assess net transfer-tagging effort proportional to abundance inside and outside and recapture effort known inside and outside (Reñones \& Goñi 2000) — are very difficult to meet (Zeller et al. 2003). Tag and release of lobsters fished outside the CIMR was attempted in 1997 with little success (low catch rates in fished areas yielded very few lobsters for tagging). Here we have avoided this problem by exploring the application of tag catch rates and of tag ratios to trace the origin of the lobsters caught in the fishery.

Species more likely to show strong responses to protection are those that are subject to high levels of fishing mortality and have limited movements in relation to the size of the protected area (Kramer \& Chapman 1999, Jennings 2001, Kelly \& MacDiarmid 2003). High exploitation rates and limited mobility of adult Palinurus elephas suggest that the size of the CIMR $(9 \times 4.5 \mathrm{~km})$ is adequate to build-up a reproductive population (Goñi et al. 2001, 2003a), while ensuring a steady supply of lobsters to the adjacent fishery. However, much remains to be understood about the migration and movement patterns of $P$. elephas in the region and with the available knowledge it is not pos- 
sible to determine the relative contribution of seasonal migrations and of density-dependent movements to spillover.

Although the geographic extent of the effects on catches observed here appears small, it measures up with the effects estimated in studies of coral reef fishes, which do not exceed a few hundred to $2000 \mathrm{~m}$ from the protected area (e.g. Russ \& Alcalá 1996, McClanahan \& Mangi 2000, Roberts et al. 2001, Russ et al. 2004, but see Yamasaki \& Kuwahara 1990). Interestingly, recent work by Parsons et al. (2003) suggests that protection in MPAs could select for individuals with the highest tendency to exhibit residential behaviour. In the CIMR this would mean that the extent of lobster spillover might have been greater, or, could decline overtime as the more mobile individuals are caught in the adjacent fishery. Highest values of POT near the CIRM boundary could indicate that the more mobile lobsters are more likely to be caught, tagged and subsequently recaptured in the fishery.

Factors other than spillover could cause the negative gradient of lobster density away from the CIMR. The CIMR could be the focus of lobster populations in the area if puerulus recruit in shallow waters (e.g. Díaz el al. 2001). However, data currently available on postpuerulus density in the CIMR suggest average to low levels of settlement relative to other areas (Goñi et al. 2003c). Alternatively, the CIMR could be a natural hotspot for Palinurus elephas and the quality of the lobster environment could decay from its centre. This concern highlights the importance of incorporating relevant environmental variables, such as habitat characteristics, in studies of reserve effects (Chapman \& Kramer 1999, García-Charton et al. 2004). Unfortunately, no detailed habitat information is available, and in fact, the CIMR could be a natural hot spot for P. elephas because fishermen continued to fish there when other fishing grounds had low catch. In hotspots, population increases following protection may be small because the habitat may be highly utilized, in which case abundance increases will result in export to adjacent areas (Jennings 2001).

In summary, because of their limited mobility relative to the size of the CIMR and the overfished status of the populations, in all likelihood Palinurus elephas responded swiftly to protection in the CIMR in terms of population density and reproductive potential (Goñi et al. 2001, 2003a). In this case, the negative gradient of lobster catch with distance from the reserve and the concentration of fishing effort on the boundaries can best be explained by a process of adult export. Our tagging data also indicates that the CIMR is supplying the adjacent fishery. This is not to say that the CIMR is providing net benefits to the fishery, as once again, lack of pre-reserve data prevents a true assessment of the potential fishery benefits of the reserve. It is important to bear in mind that understanding whether a particular marine reserve works requires that it be evaluated in the context of the goals inherent to their establishment (Palumbi 2001). Many marine reserves, including the CIMR, have been created to meet unspecified conservation benefits rather than verifiable management objectives (Jennings 2001). Thus, because location, size, and habitats protected were chosen with no particular species in mind, the post hoc evaluation of their effectiveness should not be used as tests of the benefits of marine reserves, but rather to draw lessons for establishing future reserves. In future, replicates of both reserves and harvested populations monitored before and after reserve establishment will be needed to unambiguously assess fishery benefits of reserves (Carr \& Reed 1993, Russ 2002).

Acknowledgements. We thank the skipper and crew of the 'Calypso' for their invaluable collaboration and M. C. Iglesias for editorial help. We acknowledge the helpful comments of S. A. Adlerstein and 3 anonymous referees. This work was supported by the Spanish Secretaría General de Pesca Marítima by a grant to the Instituto Español de Oceanografía for the LANGOSTA project.

\section{LITERATURE CITED}

Adlerstein SA, Welleman HC (2000) Diel variation of stomac contents of North Sea cod (Gadus morhua) during a 24-h fishing survey: an analysis using generalized additive models. Can J Fish Aquat Sci 57:2363-2367

Alcalá AC, Russ GR (1990) A direct test of the effects of protective management on abundance and yield of tropical marine resources. J Cons Int Explor Mer 46:40-47

Ashworth JS, Ormond RFG (2005) Effects of fishing pressure and trophic group on abundance and spillover across boundaries of a no-take zone. Biol Conserv 121:333-344

Attwood CG, Bennet BA (1994) Variation in dispersal of galjoen (Coracinus capensis) (Teleostei: Coracinidae) from a marine reserve. Can J Fish Aquat Sci 51:1247-1257

Botsford LW, Micheli F, Hastings A (2003) Principles for design of marine reserves. Ecol Appl 13(1):S25-S31

Carr MH, Reed DC (1993) Conceptual issues relevant to marine harvest refuges: Examples from temperate reef fishes. Can J Fish Aquat Sci 50:2019-2028

Chambers JM, Hastie TJ (1992) Statistical models in S. Advanced Books and Software, Pacific Grove, CA

Chapman MR, Kramer DL (1999) Gradients in coral reef fish density and size across the Barbados Marine Reserve boundary: effects of reserve protection and habitat characteristics. Mar Ecol Prog Ser 181:81-96

Cole RG, Villouta E, Davidson RJ (2000) Direct evidence of limited dispersal of the reef fish Parapercis colias (Pinguipedidae) within a marine reserve and adjacent fished areas. Aquatic Conserv: Mar Freshw Ecosyst 10:421-436

Côté IM, Mosqueira I, Reynolds JD (2001) Effects of marine reserve characteristics on the protection of fish populations: a meta-analysis. J Fish Biol 79(A):178-189

Crawley MJ (2003) Statistical computing. An introduction to data analysis using S-Plus. John Wiley \& Sons, Chichester 
Davidson RJ, Villouta E, Cole RG, Barrier RGF (2002) Effects of marine reserve protection on spiny lobster (Jasus edwardsii) abundance and size at Tonga Island Marine Reserve, New Zealand. Aquat Conserv12:213-227

Davis GE, Dodrill JW (1989) Recreational fishery and population dynamics of spiny lobsters, Panulirus argus, in Florida Bay, Everglades National Park, 1977-1980. Bull Mar Sci 44(1):78-88

Denis V, Lejeune J, Robin JP (2002) Spatio-temporal analysis of commercial trawler data using General Additive models: patterns of Loginid squid abundance in the north-east Atlantic. ICES J Mar Sci 59:633-648

Díaz D, Mari M, Abello P, Demestre M (2001) Settlement and juvenile habitat of the European spiny lobster Palinurus elephas (Crustacea : Decapoda : Palinuridae) in the western Mediterranean Sea. Sci Mar 65(4):347-356

Dugan JE, Davis GE (1993) Applications of marine refugia to coastal fisheries management. Can J Fish Aquat Sci 50: 2029-2042

Fretwell SD, Lucas HL (1970) On territorial behaviour and other factors influencing habitat distribution in birds. I. Theoretical development. Acta Biotheor 19:16-36

Galal N, Ormond RFG, Hassan O (2002) Effect of a network of no-take reserves in increasing catch per unit effort and stocks of exploited reef fish at Nabq, South Sinai, Egypt. Mar Freshw Res 53(2):199-205

García-Charton JA, Pérez-Ruzafa A, Sánchez-Jerez P, BayleSempere JT, Reñones O, Moreno D (2004) Multi-scale spatial heterogeneity, habitat structure, and the effect of marine reserves on Western Mediterranean rocky reef fish assemblages. Mar Biol 144:161-182

Gerber LR, Bostford LW, Hastings A, Possinham HP, Gaines SD, Palumbi S, Andelman S (2003) Population models for marine reserve design. Ecol Appl 13(1):S47-S64

Goñi R, Latrouite D (2005) Review of the biology, ecology and fisheries of Palinurus spp. species of European waters: Palinurus elephas (Fabricius, 1787) and Palinurus mauritanicus (Gruvel, 1911). Cah Biol Mar 46:127-142

Goñi R, Reñones O, Quetglas A (2000) Abundance and movement of Palinurus elephas in a Northwestern Mediterranean marine reserve. The Lobster Newsletter Volume 13(1):4-7

Goñi R, Reñones O, Quetglas A (2001) Dynamics of a protected Western Mediterranean population of the European spiny lobster Palinurus elephas (Fabricius, 1787) assessed by trap surveys. Mar Freshw Res 52:1577-1587

Goñi R, Quetglas A, Reñones O (2003a) Size at maturity, fecundity and reproductive potential of a protected population of the spiny lobster Palinurus elephas (Fabricius, 1787) from the Western Mediterranean. Mar Biol 143: 583-592

Goñi R, Quetglas A, Reñones O (2003b) Differential catchability of male and female European spiny lobster Palinurus elephas (Fabricius, 1787) in traps and trammel nets. Fish Res 65:295-307

Goñi R, Quetglas A, Reñones O (2003c) Biología, ecología, pesquerías y efecto reserva de la langosta roja, Palinurus elephas Fabricius 1787, de Columbretes y Baleares (Mediterráneo Occidental). IEO Report COB/LANGOSTA/03-1, Centro Oceanográfico de Baleares, Palma de Mallorca

Guénette S, Lauck T, Clark C (1998) Marine reserves: from Beverton and Holt to the present. Rev Fish Biol Fish 8: 251-272

Halpern BS, Warner RR (2002) Marine reserves have rapid and long lasting effects. Ecol Lett 5:361-366

Hastie T, Tibshirani R (1990) Generalized additive models. Chapman \& Hall, London
Hepper BT (1977) The fishery for crawfish, Palinurus elephas, of the coast of Cornwall. J Mar Biol Ass UK 57:925-941

Jennings S (2001) Patterns and prediction of population recovery in marine reserves. Rev Fish Biol Fish 10:209-231

Johnson DR, Funicelli NA, Bohnsack JA (1999) Effectiveness of an existing estuarine no-take fish sanctuary within the Kennedy Space Center, Florida. North Am J Fish Manage 19:436-453

Kaunda-Arara B, Rose GA (2004) Effects of marine reef National Parks on fishery CPUE in coastal Kenya. Biol Conserv 118:1-13

Kelly S (2001) Temporal variation in movement of the spiny lobster, Jasus edwardsii. Mar Freshw Res 52:323-331

Kelly S, Scott D, MacDiarmid AB (2002) The value of a spillover fishery for spiny lobsters around a marine reserve in New Zealand. Coast Manage 30:153 -166

Kelly S, MacDiarmid AB (2003) Movement patterns of mature spiny lobsters, Jasus edwadsii, from a marine reserve. New Zeal J Mar Fresh 37:149-158

Kramer DL, Chapman MR (1999) Implications for fish home range size and relocation for marine reserve function. Environ Biol Fish 55:65-79

Marin J (1987) Exploitation, biologie et dynamique du stock de langouste rouge de Corse, Palinurus elephas Fabricius. $\mathrm{PhD}$ thèse, Université de Aix, Marseille

Martell SJ, Walters CJ, Wallace SW (2000) The use of marine protected areas for conservation of lingcod (Ophidion elongatus). Bull Mar Sci 66(3):729-743

Maury O, Gascuel D (2001) 'Local overfishing' and fishing tactics: theoretical considerations and applied consequences in stock assessment studied with a numerical simulator of fisheries. Aquat Living Resour 14:203-210

McClanahan TR, Kaunda-Arara B (1996) Fishery recovery in a coral-reef marine park and its effect on the adjacent fishery. Conserv Biol 10:1187-1199

McClanahan TR, Mangi S (2000) Spillover of exploitable fishes from a marine park and its effects on the adjacent fishery. Ecol Appl 10(6):1792-1805

Millar RB, Willis TJ (1999) Estimating the relative density of snapper in and around a marine reserve using a log-linear mixed-effects model. Aust NZ J Statist 41(4):383-394

Murawski SA, Wigley SE, Fogarty MJ, Rago PJ, Mountain DG (2005) Effort distribution and catch patterns adjacent to temperate MPAs. ICES J Mar Sci 62(6):1150-1167

Palumbi S (2001) The ecology of marine protected areas. In: Bertness MD, Gaines SD, Hay ME (eds) Marine community Ecology. Sinauer Associates, Sutherland, MA, p 509-530

Parsons DM, Babcock RC, Hankin RKS, Willis RJ, Aitken JP, O'Dor RK, Jackson GD (2003) Snapper Pagrus auratus (Sparidae) home range dynamics: acoustic tagging studies in a marine reserve. Mar Ecol Prog Ser 262:253-265

Rakitin A, Kramer DL (1996) Effect of a marine reserve on the distribution of coral reef fishes in Barbados. Mar Ecol Prog Ser 131:97-113

Reñones O, Goñi R (2000) Estimating movement rates by mark-recapture methods. In: Goñi R, Harmelin-Vivien M, Badalamenti F, Le Diréach L, Bernard G (eds) Introductory guide to methods for selected studies in marine reserves. GIS Posidonie publications, Marseille, p 46-50

Roberts CM, Polunin NVC (1991) Are marine reserves effective in management of reef fisheries? Rev Fish Biol Fish 1: 65-91

Roberts CM, Polunin NVC (1993) Marine reserves: simple solutions to managing complex fisheries? Ambio 22: $363-368$ 
Roberts CM, Bohnsack JS, Gell FR, Hawkins JP, Goodridge R (2001) Effects of marine reserves on adjacent fisheries. Science 294:1920-1923

Rowe S (2001) Movement and harvesting mortality of American lobsters (Homarus americanus) tagged inside and outside no-take reserves in Bonavista Bay, Newfoundland. Can J Fish Aquat Sci 58:1336-1346

Rowley RJ (1994) Marine reserves in fisheries management. Aquat Conserv 4:233-254

Russ GR (2002) Yet another review of marine reserves as reef fishery management tools. In: Sale P (ed) Coral reef fishes. Academic Press, San Diego, CA, p 421-443

Russ GR, Alcalá AC (1996) Do marine reserves export adult fish biomass? Evidence from Apo Island, central Philippines. Mar Ecol Prog Ser 132:1-9

Russ GR, Alcalá AC, Maypa AP (2003) Spillover from marine reserves: the case of Naso vlamingii at Apo Island, the Philippines. Mar Ecol Prog Ser 264:15-20

Russ GR, Alcalá AC, Maypa AP, Calumpong HP, White AT (2004) Marine reserve benefits local fisheries. Ecol Applic 14(2):597-606

Sánchez Lizaso JL, Goñi R, Reñones O, García Chartón JA, Galzin R, Bayle J, Sánchez-Jerez P, Pérez Ruzafa A, Ramos AA (2000) Density dependence in marine protected populations: A review. Environ Conserv 27:144-158

Swartzman G, Huang C, Kaluzny S (1992) Spatial analysis of Bering Sea survey data using generalized additive models. Can J Fish Aquat Sci 49:1366-1378

Treganza T, Thompson DJ (1998) Unequal competitor ideal free distribution in fish? Evolut Ecol 12:655-666

Tremain DM, Harnden CW, Adams DH (2004) Multidirec-

Editorial responsibility: Otto Kinne (Editor-in-Chief),

Oldendorf/Luhe, Germany tional movements of sportfish species between an estuarine no-take zone and surrounding waters of the Indian River Lagoon, Florida. Fish Bull 102:533-544

Tupper M, Rudd MA (2002) Species-specific impacts of a small marine reserve on reef fish production and fishing productivity in the Turks and Caicos Islands. Environ Conserv 29(4):484-492

Venables WN, Ripley BD (2000) Modern applied statistics with S. Springer-Verlag, New York

Walters C (2000) Impacts of dispersal, ecological interactions and fishing effort dynamics on efficacy of marine protected areas: How large should protected areas be? Bull Mar Sci 6(3):745-757

Willis TJ, Millar RB, Babcock RC, Tolimieri N (2003a) Burdens of evidence and the benefits of marine reserves: Putting Descartes before des horse? Environ Conserv 30:97-103

Willis TJ, Millar RB, Babcock RC (2003b) Protection of exploited fish in temperate regions: high density and biomass of snapper Pagrus auratus (Sparidae) in northern New Zealand marine reserves. J Appl Ecol 40:214-227

Yamasaki A, Kuwahara A (1990) Preserved area to effect recovery of overfished Zuwai crab stocks off Kyoto Prefecture. Proceedings International Symposium of King and Tanner Crabs, November 1989, Anchorage, Alaska, Alaska Sea Grant, Fairbanks, AK, p 575-585

Zeller DC, Russ GR (1998) Marine reserves: patterns of adult movement of the coral trout (Plectropomus leopardus) (Serranidae). Can J Fish Aquat Sci 55:917-924

Zeller DC, Stoute SL, Russ GR (2003) Movements of reef fishes across marine reserve boundaries: effects of manipulating a density gradient. Mar Ecol Prog Ser 254:269-280

Submitted: February 11, 2005; Accepted: September 19, 2005 Proofs received from author(s): January 27, 2006 